\title{
TOURIST DESTINATION DEVELOPMENT STRATEGIES AND THE IMPACT ON TOURIST VISITS CASE STUDY: PURA GUNUNG KAWI IN SEBATU VILLAGE, GIANYAR, BALI
}

\author{
I Made Sudjana, I Made Darsana. \\ International Bali Institute of Tourism (STPBI) \\ darsana@stpbi.ac.id
}

\begin{abstract}
Pura Gunung Kawi Sebatu is a tourist destination in Bali. The temple is located in Sebatu Village, Tegallalang, Gianyar Regency. However, unlike most tourist destinations in general, Gunung Kawi Temple is infrequently visited by both foreign and domestic tourists, especially when compared with similar destinations, such as Pura Tirta Empul Tampaksiring. The purpose of this study was to determine the development strategy of "Pura Gunung Kawi Sebatu" and the impact of tourist visits on the welfare of the community in Sebatu Village. This study used a qualitative descriptive approach which aimed to describe, record, analyze, and interpret current conditions of Pura Gunung Kawi Sebatu. The results from this study was the development strategies of Pura Gunung Kawi relied on some factors such as: the stability of various levels, named; security, comfort, support facilities and infrastructure; the quality and quantity of human resources; partnerships with funding agencies; the linkage function development of tourism activities; increasing community participation in tourism development; and programs implementation for effective promotion on an ongoing basis. These stabilities helped increase the number of tourist visits, which leads to community's welfare in the area surrounding Pura Gunung Kawi Sebatu.
\end{abstract}

Keyword(s) : Tourist destination development strategy, community welfare, Pura Gunung Kawi Sebatu.

\section{INTRODUCTION}

Tourism is an important sector in economy. It provides major contribution to a region and is recognized as an important factor in regional development (Commission of the European Communities, 2010). Gianyar Regency in Bali has various kind of cultural diversity such as dance, percussion, chisels, painting, and crafts, all of which are popular attraction for tourists. Before tourism became popular in Bali, arts activities were conducted solely for religious ceremonies, but as tourism become an indispensable part of people's livelihood, arts were commercialized to serve tourism, which includes the art of dance and tabuh/gamelan, as well as painting, sculpture, all of which generates special attraction for tourists. Nowadays, the tourism sector is one of the leading sectors of Gianyar in generating the region's revenue. Therefore the utilization, development, management and financing of the tourist areas should receive serious attention by involving the institutions of local government, stakeholders and the participation of the local community in various policies and programs which will be used for the development of tourist destinations in Gianyar. The tourist destination promotion 
program is one example of the efforts that could be taken in order to stay competitive in tourism sector of the global era (Anh, 2012). One of the tourist destinations with considerable potential to be developed in Gianyar-Bali is "Pura Gunung Kawi Sebatu".

Pura Gunung Kawi is one of the temples in Bali of which the surrounding areas are full of art and tourism activities. The temple itself is located in the village of Sebatu, District Tegallalang, Gianyar Region. Pura Gunung Kawi has many springs and pools of water, all of which are arranged artistically to make this temple have charming and exotic natural scenery. This temple sacred atmosphere is considered as perfect condition to conduct prayers at Sang Hyang Widhi and His manifestation Sang Hyang Vishnu and is a great place to train the soul, should one desires to do so. Pura Gunung Kawi Sebatu also had Wantilan, some Pelinggih, Bale in addition to many Padmasana as parts of the temple itself. There are two types of visitor in Pura Gunung Kawi, visitors who come here to worship/pray and visitors who only wanted to see the beauty of Pura Gunung Kawi Sebatu. The visitors who come to pray are not charged admission fee, while the visitors who come for sightseeing are charged with an entrance fee and provided some kamen or simple Balinese praying costume to be worn inside the temple, as the temple is considered a sacred and holy place by Balinese Hindus. Activities of religious ceremonies are often held in this temple like; Piodalan and Pujawali. The quantity of tourists visits both foreign and local travelers, on average only reaches 50 people a day. The number of visits is relatively small compared to other similar destinations in Gianyar. In fact, even though the temple has similar qualities in natural beauty and spiritual meanings as other temples i.e. Tirta Empul Temple, the number of visits per day is noticeably much smaller. Therefore there is a need to formulate and optimize the development strategies for Pura Gunung Kawi as travel destination to increase tourist visits and find out if whether there is any impact of the temple development for the welfare of local communities in the surrounding area.

\section{LITERATURE REVIEW}

Information is the key factor to determine the tourism development vision and strategy for its achievement. According to Ritchie and Crouch (2003), strategic analysis is a key factor in the process of influencing the main competition objectives regarding the effectiveness of the tourist destinations development strategy. Tourism may respond strongly enough to changes in various factors in the economy, politics, law and demographics (Evans, Campbell \& Stonehouse, 2003). External strategic analysis should be incorporated in the development of the tourism market and should be able to identify the main trends of the tourist destinations (Cooper at all., 2008). Analysis of the tourism sector should be followed by detailed analysis to be able to face the increasingly fierce competition. The goals of destination development strategy are the ability to face its competitors, increase the number of visitors to the area, as well the quality of the offered service. Equally important are the abilities to identify tourist destinations, recognize the strengths and weaknesses to determine the strategic position in the tourism market (Ritchie \& Crouch, 2003). 
Another important part of internal strategic analysis is the capability to develop tourist destination. The results of external and internal strategic analysis are then summarized in SWOT analysis to identify key factors for development of tourist destinations, followed by the definition of long-term vision and key strategic objectives. The vision reflects the main direction of the destination, outlining the directions in more detail. The proposed strategy is hopefully able to achieve the goal. The formulation of the strategy must support the development of internal resources, the ability to take advantage of future opportunities as effectively as possible and be able to anticipate the threat from the outside. The formulation should also be able to reduce weaknesses to meet the interests of key stakeholders and travelers' demand (Johnson et al., 2008). The implementation phase of the strategy identifies specific conditions to be converted into practice. The process should be able to be realized with proper specifications and accountability adjusted with necessary resources. The important part of this phase is the existence of control mechanisms to monitor the results obtained from the implemented strategic system (Johnson et al., 2008).

\section{METHODOLOGY}

Every scientific research must be conducted with proper methodology. A researcher has to understand research methodology as a set of knowledge which is systematic and logical steps on data research regarding specific issues. In the education world, the popular research approach was divided into two, namely qualitative and quantitative research. In this study, researchers used a qualitative approach which emphasized more on the meaning and process rather than the outcome of an activity. Bagman and Taylor define qualitative method as a research procedure that produces the data description in the form of written or spoken words from observation of human behavior. While Kirk and Miller (2005) define that qualitative research is a tradition in social science that is fundamentally dependent on observations of human in its own region and connected with these people in their discussion and terminologies (Sudarto, 1996).

In general, qualitative research aimed to understand the symbolized meaning in people's behavior from the perspective of the community itself (Suprayogo, 2001). Qualitative research is a method to find the truth, and classified as a research built on theories that developed from researches and controlled on empirical basis. This qualitative study not only shows data as it is but also seeks to interpret a correlation as applicable factors which include viewpoints or ongoing processes. Qualitative research methods by Lexy J. Moleong (2007) is based on a foundation of research, the research paradigm, the formulation of the problem, the stages of research, research techniques, criteria and examination techniques and data analysis and interpretation of data (Sudarto, 1995: 63-64).

Based on descriptions above, this research was descriptive qualitative which studied the existing problems and working procedures in effect. There will be attempts to describe, record, analyze and interpret the current conditions. In other words, this research aimed to obtain available information about the existing situation (Mardalis, 1999: 26). In other words, the descriptive qualitative research 
is designed to collect information about the actual situations (Convelo G, 1993: 71). In essence, descriptive qualitative research is a method in researching the status of a group of people or an object with the aim of making descriptive picture or painting in a systematic, factual and accurate information on the facts or phenomena investigated (Convelo G, 1993: 76).

\section{RESULTS}

The problems faced by stakeholders in regard to the development of Pura Gunung Kawi Sebatu and the surrounding areas are as follows:

1. Limited support for facilities and infrastructure is a problem that needs immediate attention. The support for infrastructure is an important factor to achieve sustainability of tourism activities; with said support includes providing access, accommodation, transportation, travel, and other supporting infrastructure. There are many other potential tourist areas that are not supported by adequate infrastructure. The available infrastructure is built towards local use only, which is not enough to meet the needs of tourism operation in or outside the area. For instance, tourist transportation might be easily accessible in tourist area, but transportation to reach the destination from outside area is not yet widely available.

2. Limited cost or budget for the development of tourism sector.

3. Lack of competent human resources with the ability to look at the opportunities and challenges of the tourism sector, especially in Sebatu, Gianyar-Bali.

4. The lack of proper coordination among local government agencies and the stakeholders in tourism. For example the relationship between the local government in cooperation with employers, attraction managers, hotels, restaurants, transportation, telecommunications, and travel guides.

5. Minimal and ineffective marketing and promotion program, which uses a professional approach, a partnership between the private and public sector to strengthening institutional networks, and increase tourist visits on both foreign and domestic tourists.
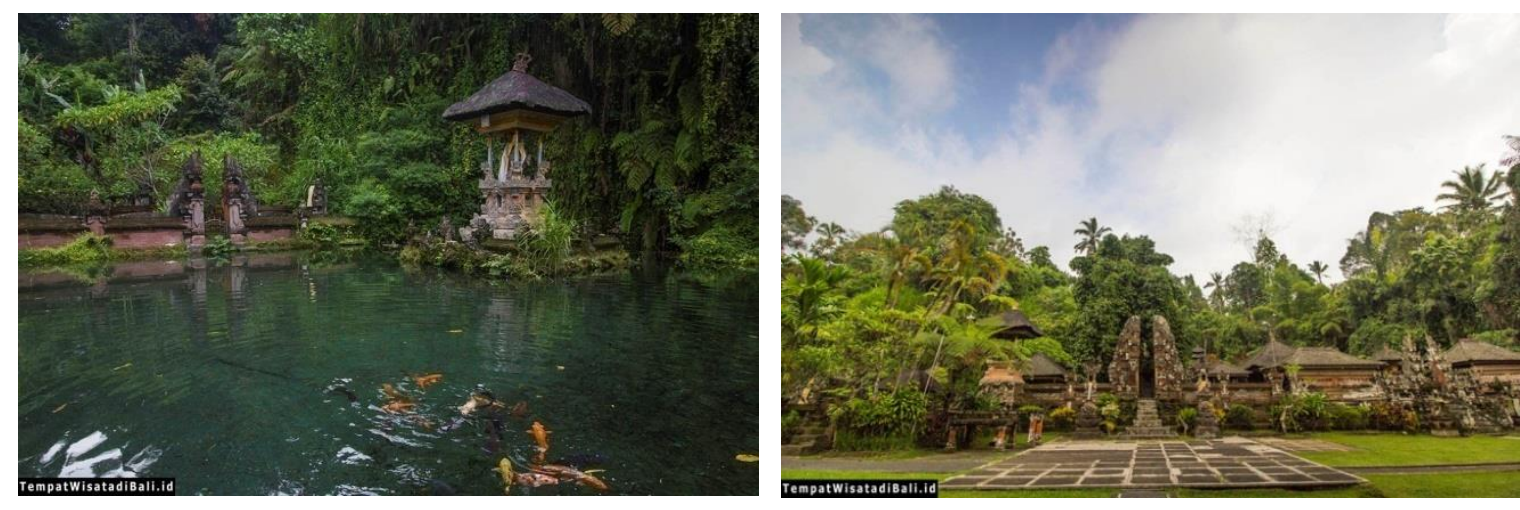

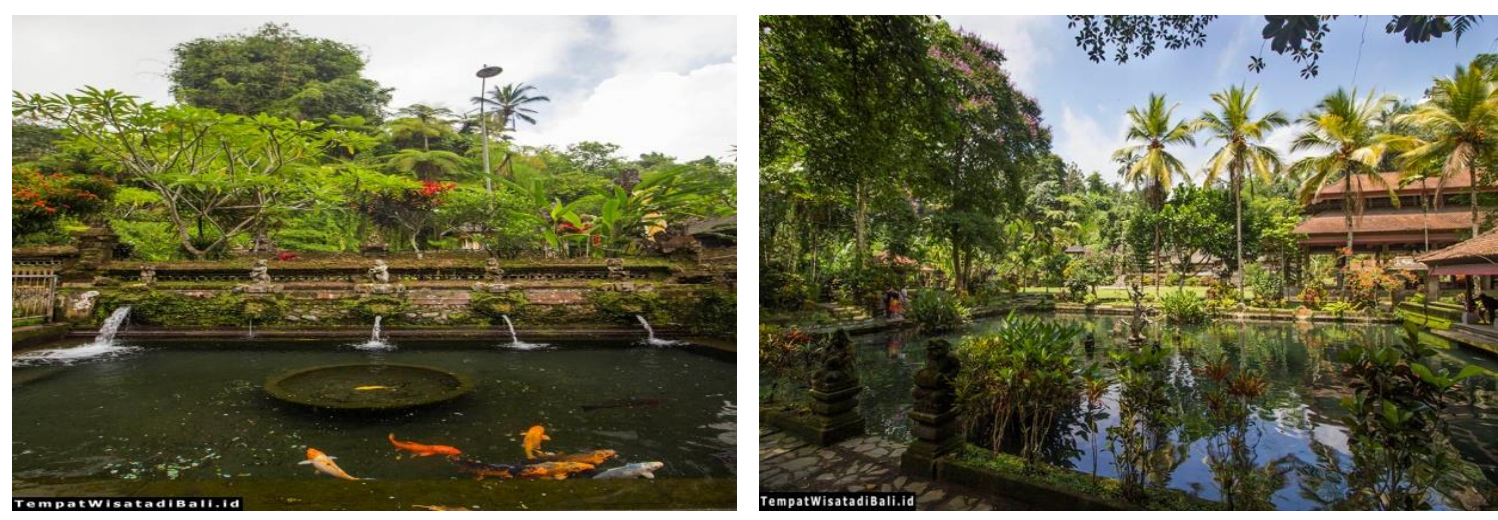

Picture 1: Tourist destination "Pura Gunung Kawi Sebatu."

Overall, a professionally managed tourism, which includes aspects of human resources and technology with proper management strategies, will have an impact on the following matters:

a. Poverty Alleviation.

Tourism development should be able to provide good work opportunities for all people. Tourist visits to the region should give out as much as a possible benefit to improve the welfare of the community. This will leads to poverty alleviation in many poor regions.

b. Sustainable Development.

While tourism activities that offer natural beauty, rich culture, and hospitality service used up quite a few resources are to support these activities, based on a variety of examples, a good management of tourism, the environment and community conditions in a tourist destination should be able to overcome these and experience a significant improvement as a result of tourism development in a region.

c. Culture Preservation.

Tourism development should be able to contribute significantly in efforts to preserve the culture of a country or a region which includes protection, development, and utilization of local culture. UNESCO and UN-WTO through their joint resolution in 2002 had stated that tourism activities are the main tool of cultural preservation. In that context, it is considered proper for Indonesia to make the development of tourism as a driving force of cultural preservation in different regions.

d. Meeting the Needs of Life and Human Rights.

Tourism has become a basic requirement of modern society. Some even said that traveling is one of human rights, especially through the provision of a longer vacation time and paid holidays schemes.

e. Improved Economy and Industry.

Good management and sustainable tourism should be able to provide an opportunity for economic growth in a tourism destination. The use of local materials and products in the field of tourism will also provide the opportunity 
for local industry to play a role in providing goods and services. The main requirement needed is the ability of the local tourism business in providing world-class service by using local materials and product quality.

f. Technology development.

With the increasingly complex and high level of competition in bringing tourists to a destination, the need for high-tech industries, especially technology will encourage tourism destinations to develop the applicability of their latest technology. In these areas, there will be the development of advanced and appropriately-used technologies to provide support for other economic activities. Thus, development of tourism will benefit the community and the government in various areas and fundamentals. Tourism will become an integral part of regional development and integration within the framework to improve the welfare of local communities.

With reference to the above explanations, strengths, weaknesses and opportunities of tourism development in tourist destinations Pura Gunung Kawi Sebatu, Gianyar-Bali, can be identified in the following table:

\begin{tabular}{|c|c|c|}
\hline Strengths & Weaknesses & Opportunities \\
\hline $\begin{array}{l}\text { - Cultural diversity } \\
\text { - Various natural attraction } \\
\text { sites } \\
\text { - Various activities for } \\
\text { tourist } \\
\text { - Unique living culture of } \\
\text { local community. }\end{array}$ & $\begin{array}{l}\text { - The packaging of attractions } \\
\text { - Lack of products diversification } \\
\text { - The management of } \\
\text { attractions } \\
\text { - The quality of various services } \\
\text { - Disparities in tourism } \\
\text { development } \\
\text { - Interpretation, }\end{array}$ & $\begin{array}{l}\text { - Locals hospitality } \\
\text { - Pluralistic society } \\
\text { - Total numbers of } \\
\text { locals } \\
\text { participation }\end{array}$ \\
\hline
\end{tabular}

\section{DISCUSSION}

In addition to the above-mentioned conditions, the region encountered a dilemma (paradox) regarding the development of tourism industry in Gianyar, especially in Sebatu. The very nature of investments in the tourism industry is "High Investment, Not Quick Yield" which means the investment in tourism requires substantial investment with long term returns. This condition is really of no interest to most stakeholders which still adopting the mindset "Instant and Shortcut", where they prefer to invest in something that results in immediate benefit. By this very nature, some investors simply lost their interest to invest in developing tourism business. In this context, it's necessary to integrate the tourism industry (tourism business integration) which is a synergy of actors in tourism both horizontally and vertically and provide benefits for each party. Therefore it requires some forms of incentives that can stimulate the investment in tourism using a participatory management by involving all stakeholders such as local communities, businesses, financial institutions, local governments (provincial and district), as well as central government. In accordance with the Strategic Plan of Development of National 
Culture and Tourism in 2005 - 2009, the national tourism development policies were directed in:

a. Increasing the competitiveness of destinations, products, and national tourism businesses;

b. Increasing market share through integrated tourism marketing in both domestic and abroad;

c. Improvement of quality, service, and travel information;

d. Development of incentive system for efforts and investments in tourism;

e. Development of tourism infrastructure;

f. Development of human resources (standardization, accreditation and certification of competencies);

g. The synergy of multi-stakeholders in designing the tourism program;

To overcome the problems and potential that has been mentioned above with reference to the policy of tourism development, it is necessary to do a series of actions based on the strategy:

a. Fiscal policy, by providing various fiscal policies for the development of tourism in various regions, particularly in the eastern region of Indonesia, such as tax holidays, capital support, and competitive loan interest.

b. Investment policy through the implementation of laws and regulations at both the national and local government that is conducive to the development of both new tourism businesses and existing businesses.

c. Infrastructure development by increasing the accessibility to and within the tourism destination through the development and expansion of road networks, airports, seaports, telecommunication networks, provision of electricity and clean water. Adequate availability of infrastructure will enhance the competitiveness and attractiveness in the provision of tourism facilities in a particular area.

d. Human resources development through improved education and training activities for local communities to develop competency in the provision of goods as well as services for both domestic and foreign tourists.

e. Cross-sector coordination to develop partnerships between all stakeholders of the tourism development through coordination, synchronization, and consolidation involving non-governmental organizations, associations/tourism businesses, People's Representative Council (DPR/DPRD), and government.

The entire conditions above require new approaches aimed at increasing the competitive advantage of Indonesia in the development of tourism. Porter (2004) states that competitive advantage requires building factors such as:

a. Cost Advantages.

Superiority over cost incurred in the provision of travel products and services is an important factor in building a competitive advantage of tourism destination. There are various factors to develop in destinations such as performance planning (design), tourism product development, marketing, service, and price. In the context of the government, the cost advantage could be realized by harmonizing regulations between central and local government related to financial incentives, tariffs and taxation schemes or levy. 
b. Differentiation.

Distinguishing destinations and tourism products are the focus of comparative advantage in developing tourism. A tourism destination should be able to distinguish itself from competitors in terms of offering unique accessibility, attractions and amenities for tourists. It is not enough to differentiate by just offering lower prices of products and services.

c. Business Linkages.

Develop a mutually beneficial relationship is an integrative process in building competitive advantage of tourism. Relationships are built vertically and horizontally as well as integrated with each other.

d. Services.

Consistent service since tourists arrived at the entry point, while in the tourism destinations, and until their return. All relevant parties such as airports and ports administrator, immigration officers, customs and quarantine, taxi drivers and others should be able to provide excellent services and standards that left a deep impression for tourists.

e. Infrastructures.

Maintaining and operating tourism infrastructure and facilities properly is also an important factor to build competitive advantage of tourism destinations.

f. Technology.

The use of appropriate technology and ease of use will be able to provide support for tourists' services in addition and support the decision-making process in the development, management and marketing of tourism destinations.

g. Human Resources.

The competence of human resources on the development of tourism services is vital for the implementation of various factors that form competitive advantages.

These various factors that form the competitive advantages illustrate the complexity of multi-sector and multidisciplinary tourism development for the central, provincial and local levels. However, to implement this successfully requires three essential elements, namely a) Vision; b) Leadership; and c) Commitments. All three of these elements must be present in the process of development, management, and marketing of tourism. In Indonesia, the implementation of the three elements mentioned above has been done by the issuance of Presidential Decree No. 16 Year 2005 on Policy Development of Culture and Tourism.

\section{Coordination and Inter-Stakeholder Cooperation in the Development of Tourism Region}

The definition of coordination by Stoner (in Dann Sugandha, 1988) is the process of unifying the blend of goals and activities of separate units in order to achieve organizational goals efficiently. Leonard D. White (in Sutarto, 1998) defines coordination as the adjustment of various organizational units within each activity so that each part contributing to optimal overall result. The conclusions withdrawn from these experts' opinions above are as follows: 
1. A unit within an organization cannot function properly without the assistance of other units.

2. To achieve the objectives of the organization, each unit is obliged to support the functional implementation of other units comprehensively and integrally.

The concept of coordination contains the need for integration, communication and implementation of the tasks as well as the interdependence of organizational units. Hani Handoko (1995) suggests three basic components that must be considered as a basic mechanism for achieving effective coordination as follows:

1. Managerial hierarchy is a chain of command, the flow of information and work, formal authority, responsible relationships, and clear accountability to generate integration if clearly defined and implemented with the proper guidance.

2. Rules and procedures are managerial decisions made for handling routine events, so it can be effective tools for coordination and constant supervision.

3. Planning and setting goals as a means of coordination by directing the entire existing organizational unit.

The benefits of the implementation of integrated and systematic coordination (Sutarto, 1998) are as follows:

1. Avoiding critical opinions or feelings from one or more organizational units.

2. Avoid disjointed feelings between organizations.

3. Avoiding conflicts between officials or among existing organizational units.

4. Avoiding the seizure of facilities owned by the organization.

5. Avoiding the wait between each organizational unit.

6. Avoid twinning execution of an organization's activities, as well as work vacancy.

7. Unity of steps and actions taken, as well as mutual helping between officials or existing organizational unit.

Therefore, it can be concluded that there are several important aspects of the concept of coordination application as follows:

1. There are organizational units and individuals with different functions within the framework of the overall organization.

2. There are various resources such as labor, skills, and knowledge of technology, budget and other working facilities that contribute to organizational success.

3. There exists a series of activities conducted by individuals and organizational units.

4. There exists a sense of unity among all activities both at the individual and organizational units.

5. There is a harmony for the activities that were carried out systematically with proper working time, thus avoided the duplication or vacancy of organizational activities.

6. Recognizing the same direction for organizational unit to move on the same goal or objective. 
7. With good coordination between government agencies, stakeholders, and public, a close cooperation is expected to be established in order to achieve the expected goals.

\section{CONCLUSIONS AND RECOMMENDATIONS}

The development of tourism in the surrounding area of "Pura Gunung Kawi" in Sebatu Village, Gianyar, Bali, emerged as a new industry and is expected to boost revenues. Both the government and local communities are working hard to develop this sector in order to achieve the welfare of local communities. Therefore, the management, development, and financing of tourism area require involvement and support of many stakeholders (public, private, and society) in order to ensure the process will run smoothly. However, the successful development of this area is also heavily influenced by certain conditions such as security and political stability, the competence of human resources, the budget used to develop the facilities and infrastructure of the tourist areas, legal policies that provide convenience, transparency and convenience for both investors and tourists to invest and enjoy the tourist areas, as well as dissemination and promotion of tourist areas development and utilization.

Based on the identification and analysis of the outlined problems, these are some recommendations that need to be considered in order to develop tourist destinations, particularly "Pura Gunung Kawi Sebatu", as follows:

1. Maintain a good and stable security of the area, in order to increase the attractiveness factor for tourists as well as local and foreign investors to visit or invest in the tourism sector.

2. The tourism sector is the tertiary sector where the traveler preferences are determined by the level of comfort, the support facilities, and infrastructure to improve accessibility to the site of tourist attraction, such as the development of national transport network, regional, and local levels.

3. Improve the quality and quantity of human resources as a stakeholder in the field of tourism through both formal and/or non-formal education. In order to achieve this, the system and mechanisms of education and training need to be designed properly, to prepare for future challenges, particularly the demands of creating apparatus with competitive edge, reliable, effective, and efficient.

4. Develop partnerships with financial institutions (banks and non-banks), both from government and private institutions, in order to create new investments to develop tourist destinations.

5. To achieve successful development of tourism activities, the process needs to be carried out with proper coordination and integrated between all concerned parties to develop integration across sectors and avoid conflicts between sectors. Improving linkages in the development of tourism activity function with other sectors to provide high value of efficiency and acceleration of regional growth is a must. The development of tourism must be associated with the development of local economy and the region itself. Tourism development should involve all stakeholders. In this context, the local communities must have a role in starting 
the upstream sector (providing extractive production activities) to the downstream activities (production services).

6. Increase community participation in tourism development and the implementation. Local community should be involved in conducting tourism activities, this way the benefits will be felt directly by the people.

7. Implement effective promotion programs on an ongoing basis, in order to increase the number of tourist visits by both domestic and international tourists.

\section{REFERENCES}

Anh, P. (2012). Identifying and Improving the Images of Vietnam as a Tourism Destination Among Finnish Tourists. (Unpublished Bachelors Dissertation). HAMK University of Applied Sciences, Valkeakoski.

Cevilla, C. G. et.al. 1993. Pangantar Metode Penelitian, Jakarta: Universitas Indonesia.

Commission of the European Communities. (2010)

Commission of the European Communities. (2010). Europe, the world's No 1 tourist destination - a new political framework for tourism in Europe. COM (2010) 352 final. Brussels. Retrieved from http://ec.europa.eu/enterprise/sectors/tourism/files/Communications/co mmunication2010_en.pdf.

Cooper, Ch., Fletcher, J., Fyall, A., Gilbert, D. \& Wanhill, S. (2008). Tourism: Principles and Practice. Harlow: Pearson Education.

Evans, N., Campbell, D. \& Stonehouse, G. (2003). Strategic Management for Travel and Tourism.Oxford: Butterworth-Heinemann.

Imam Suprayogo, T. (2001). Metodologi Penelitian Sosial-Agama, Bandung:Remaja.

Johnson, G., Scholes, K. \& Whittington, R. (2008). Exploring Corporate Strategy: Text \& Cases. Harlow: Prentice Hall.

Mardalis. (1999). Metode Penelitian: Suatu Pendekatan Proposal. Jakarta: PT Bumi Aksara.

Moleong, L. J. (2005). Metodologi Penelitian Kualitatif. Bandung : Remaja Roskarya.

perspective. Wallingford:CABI Publishing. http://dx.doi.org/10.1079/780851996646.0000.

Ritchie, J. R. B. \& Crouch, G. I. (2003). The competitive destination: a sustainable tourism

Wisata Bali Sempurna. (2017). Pura Gunung Kawi Sebatu. Retrieved from http://wisata-bali.com/pura-gunung-kawi-sebatu.html/2017

WisataBali4U. (2013, March 2). Wisata Pura Gunung Kawi Sebatu. Retrieved from https://wisatabali4u.wordpress.com/2013/03/02/pura-gunung-kawisebatu 